\title{
STUDI PENURUNAN KANDUNGAN BOD5 5 , COD, TSS, DAN WARNA PADA AIR LIMBAH INDUSTRI PENCELUPAN KAIN MENGGUNAKAN METODE LAHAN BASAH BUATAN (CONSTRUCTED WETLAND)
}

\section{STUDY OF REMOVAL EFFICIENCY OF BOD ${ }_{5}$, COD, TSS AND COLOR CONTAINMENT IN WASTE DYEING INDUSTRY USING CONSTRUCTED WETLAND METHOD}

\author{
I Gede Herry Purnama ${ }^{1}$, Ni Made Utami Dwipayanti ${ }^{2}$ \\ ${ }^{1,2}$ Program Studi Ilmu Kesehatan Masyarakat, Fakultas Kedokteran, \\ Universitas Udayana, Denpasar-Bali \\ ${ }^{1}$ Email: patjoel@yahoo.com
}

\begin{abstract}
INTISARI
Pewarnaan sebagai bagian dari proses produksi industri tekstil menghasilkan air limbah yang berpengaruh pada badan air dan berbahaya bagi kehidupan organisme yang ada di air, karena mengandung kandungan organik yang tinggi dan intensitas warna yang tinggi. Oleh karena itu diperlukan suatu upaya pengolahan air limbah tersebut sebelum masuk ke badan air. Penelitian ini menggunakan metode lahan basah (Constructed Wetland) tanaman air mengambang dengan tanaman eceng gondok (Eichornia crassipes) dengan tujuan untuk mendapatkan tingkat efisiensi penyisihan kandungan $\mathrm{BOD}_{5}$, COD, TSS, dan warna dari air limbah industri pencelupan.

Penelitian ini berskala laboratorium untuk meneliti efisiensi pengaruh dari pemakaian tanaman pada proses pengolahan air limbah. Penelitian ini termasuk penelitian deskriptif kuantitatif dengan pemeriksaan $\mathrm{BOD}_{5}, \mathrm{COD}$, TSS, dan intensitas warna dari air limbah industri pencelupan.

Hasil dari penelitian ini menunjukan efisiensi penyisihan kandungan BOD 1 11,06\% - 53,09\%, COD 8,31\% - 55,22\%, TSS $6,84 \%,-59,47 \%$, dan intensitas warna $7,54 \%$ - 34,8\% pada kisaran $\mathrm{pH}$ berkisar 7,33 - 8,90. Organic loading rate reaktor constructed wetland diperoleh 424,57 kg/ha.hari sampai 2233,88 kg/ha.hari Hasil ini menyimpulkan bahwa metode lahan basah menggunakan eceng gondok memiliki efisiensi penyisihan $\mathrm{BOD}_{5}$, COD, TSS, dan warna yang rendah. Hal ini ditunjang dengan hasil penelitian dengan batch reactor yang menunjukan tingkat penyerapan warna oleh tanaman Eceng Gondok tanpa pengolahan pendahuluan juga masih rendah. Selain itu pada percobaan kontinyu masih ada sampel effluent yang lebih tinggi dari standar baku mutu Kep.Men.51/Men.LH/10/1995.
\end{abstract}

Kata kunci: efisiensi pengolahan, air limbah tekstil, lahan basah, eceng gondok

\section{ABSTRACT}

Dyeing industries as part of textile processess produce wastewater which affect water bodies and harmfull for living organism in water caused by moderate organic compounds and high color. This study use free floating macrophytes constructed wetland methods with water hyacinth plant (Eichornia crassipes) to determine level of removal efficiency of BOD 5 , COD, TSS, and color intensity of wastewater from one of dyeing industry in Denpasar.

Experiment was carried out in a laboratory scale to study the influence of plant on the treatment efficiency of waste water. This study was descriptive quantitative with $\mathrm{BOD}_{5}, \mathrm{COD}$, TSS, and color intensity testing from dyeing wastewater.

The result of the experiment shows the removal efficiency of $\mathrm{BOD}_{5}$ is $11,06 \%-53,09 \%$, COD is $8,31 \%-55,22 \%$, TSS is $6,84 \%$, $-59,47 \%$, and color intensity is $7,54 \%-34,8 \%$ and the $\mathrm{pH}$ range is $7,33-8,90$. Organic loading rate range is $424,57 \mathrm{~kg} / \mathrm{ha} . \mathrm{d}-2233,88$ $\mathrm{kg} /$ ha.d. It summarized that constructed wetland using water hyacinth has low $\mathrm{BOD}_{5}, \mathrm{COD}, \mathrm{TSS}$, and color removal efficiency due to some effluent sample are higher than quality standard of Kep.Men.51/Men.LH/10/1995. Furthermore, the batch reactor test with no prior treatment result showed water hyacinth has low efficieny to remove color from dyeing waste water.

Keywords: removal efficiency, dyeing wastewater, constructed wetland, water hyacinth

\section{PENDAHULUAN}

Industri tekstil menghasilkan limbah cair berwarna yang dapat mempengaruhi secara fisik, kimia, maupun biologi. Air yang telah tercemar limbah industri pencelupan juga tidak dapat dimanfaatkan lagi untuk keperluan sehari - hari karena tidak memenuhi syarat untuk dipergunakan kembali. Perlindungan badan air dari pencemaran seharusnya merupakan bagian dari proses industri secara integratif (Suyasa and Dwijani, 2007).

Tingginya intensitas warna pada air limbah tekstil disebabkan karena sekitar $40 \%$ dari zat warna reaktif azo yang digunakan dalam proses pencelupan kain terbuang sebagai limbah sedangkan kandungan bahan organik dan kimia sangat tinggi terkait dengan bahan-bahan yang digunakan dalam proses tekstil seperti enzim, detergen, zat warna dan bahanbahan tambahan lainnya (Sastrawidana et al., 2008).

Belum banyak penelitian tentang zat warna tekstil dengan cara biologis yang menggunakan air limbah tekstil yang sebenarnya pada industri tekstil dimana mengandung bahan pewarna dan bahan - bahan lainnya yang menunjang proses produksi industri tekstil. Berdasarkan hal tersebut maka penulis tertarik melakukan penelitian untuk mengetahui efisiensi sistem lahan basah buatan (Constructed Wetland) dengan tanaman Eceng Gondok (Eichornia crassipes) untuk menurunkan kadar $\mathrm{BOD}_{5}$, COD, TSS dan Warna.

\section{MATERI DAN METODE}

\section{Rancangan Penelitian}

Penelitian ini merupakan studi experimental skala lapangan untuk melihat efisiensi penyisihan parameter $\mathrm{BOD}_{5}$, COD, TSS dan warna air limbah industri pencelupan, dimana data yang diperoleh akan diolah secara deskriptif kuantitatif.

Penelitian dilakukan di perusahaan pencelupan CV. Tata Warna dan analisis laboratorium akan dilakukan di laboratorium bersama PSKM, Fakultas Kedokteran Universitas Udayana dan Laboratorium Daerah Provinsi Bali 
Tampilan data akan disajikan secara deskriptif dengan metode grafik dan tabel untuk melihat efisiensi penyisihan kandungan $\mathrm{BOD}_{5}, \mathrm{COD}$, TSS, dan Warna pada sampel air limbah. Data akan dianalisis secara deskriptif kuantitatif. Untuk penentuan tingkat kinerja dari constructed wetland dalam menurunkan konsentrasi BOD5, COD, TSS, dan warna, dihitung dengan persamaan yaitu:

$$
\text { Efisiensi }(\%)=\frac{\mathrm{Co}-\mathrm{Ce}}{\mathrm{Co}} \times 100 \%
$$

Dimana :

$$
\begin{array}{ll}
\mathrm{Co} & =\text { Konsentrasi awal }(\mathrm{Mg} / \mathrm{L}) \\
\mathrm{Ce} & =\text { Konsentrasi akhir }(\mathrm{Mg} / \mathrm{L})
\end{array}
$$

\section{Variabel penelitian dan definisi operasional}

Dalam penelitian ini terdapat beberapa variable parameter air limbah yang akan dipantau adalah BOD, COD, TSS dan warna untuk dapat melihat efisiensi penyisihan sebagai kinerja sistem pengolahan.

a. Air Limbah industri tekstil adalah air limbah industry pencelupan yang diperoleh dari salah satu industry pencelupan yang beroperasi di kota Denpasar.

b. Influen adalah aliran air limbah masuk yang belum terolah yang akan dipantau baik kuantitas (debit dlm ltr/menit) dan kualitas (parameter COD, TSS, warna dan, $\mathrm{pH})$

c. Sistem Pengolahan Air Limbah adalah suatu gabungan unit pengolahan air limbah yang dirangkaikan untuk mencapai suatu efisiensi penyisihan kandungan air limbah yang diinginkan.

d. Unit Anaerobic Baffled Reactor adalah reactor pengolahan air limbah yang didesain sedemikan rupa menggunakan susunan buffle yang beroperasi memanfaatkan bakteri dalam lingkungan anaerobic untuk mengolah limbah organic.

\section{Konsep dan tahapan penelitian}

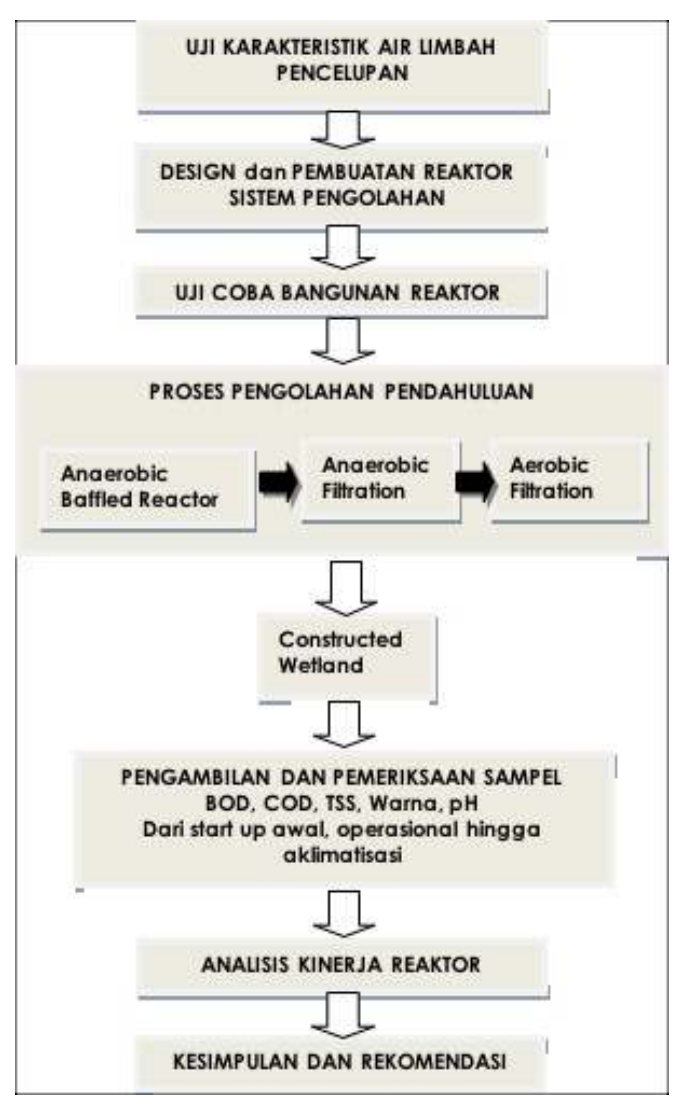

Gambar 1. Konsep dan tahapan penelitian

\section{Teknik pengambilan sampel}

Sampel air limbah pencelupan diambil pada titik inlet sebelum perlakuan dengan constructed wetland dan pada titik outlet setelah perlakuan, dengan metode grab sampel yaitu pengambilan sesaat. Sampel yang diambil sebanyak \pm 1 liter. Sampel diambil secara bersamaan pada inlet dan outlet setiap 1 minggu sekali. Sampel ditempatkan pada cooler box untuk menjaga suhu dan langsung dibawa ke laboratorium.

\section{HASIL PENELITIAN}

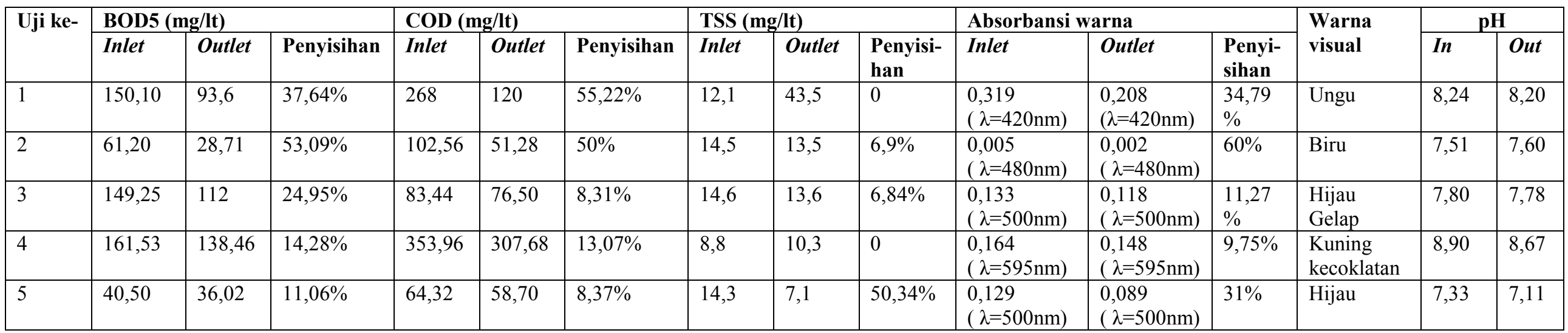




\begin{tabular}{|l|l|l|l|l|l|l|l|l|l|l|l|l|l|l|l|l|l}
\hline 6 & 32,40 & 28,80 & $11,11 \%$ & 77,60 & 40,25 & $48,13 \%$ & 19,7 & 12,1 & $38,57 \%$ & $\begin{array}{l}0,278 \\
(\lambda=500 \mathrm{~nm})\end{array}$ & $\begin{array}{l}0,236 \\
(\lambda=500 \mathrm{~nm})\end{array}$ & $\begin{array}{l}15,10 \\
\text { Hijau gelap }\end{array}$ & $\begin{array}{l}7,40 \\
7,42\end{array}$ \\
\hline 7 & 30,70 & 24,60 & $19,86 \%$ & 76,35 & 38,25 & $49,9 \%$ & 19,0 & 7,7 & $59,47 \%$ & $\begin{array}{l}0,011 \\
(\lambda=800 \mathrm{~nm})\end{array}$ & $\begin{array}{l}0,009 \\
(\lambda=500 \mathrm{~nm})\end{array}$ & $\begin{array}{l}18,18 \\
\%\end{array}$ & $\begin{array}{l}\text { Hitam } \\
(\lambda, 11\end{array}$ & \begin{tabular}{l}
8,03 \\
\hline
\end{tabular}
\end{tabular}

Sumber: Hasil penelitian

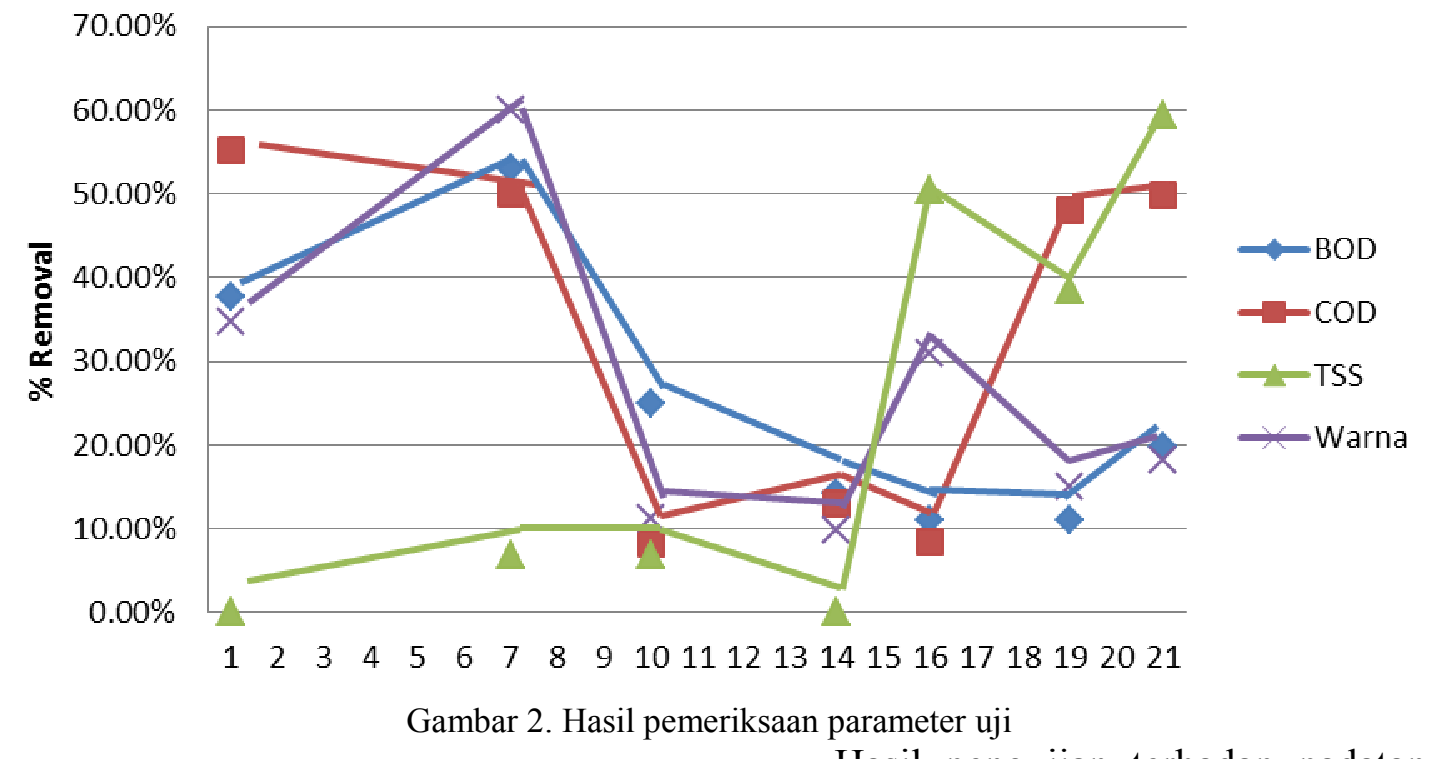

\section{PEMBAHASAN}

Dari hasil seluruh parameter yang diujikan rata - rata hasil yang diperoleh dari pengolahan dengan metode constructed wetland dengan tanaman Eceng Gondok masih memiliki efisiensi yang terbilang cukup rendah. Efisiensi yang didapatkan untuk parameter $\mathrm{BOD}_{5}, \mathrm{COD}$, TSS, dan warna adalah $24,57 \%, 33,29 \%, 32,42 \%$, dan $19,06 \%$.

Jika dilihat berdasarkan grafik efisiensi penyisihan parameter $\mathrm{BOD}_{5}, \mathrm{COD}$, dan warna, reaktor constructed wetland memiliki efisiensi yang baik pada awal penelitian.Tetapi pada parameter TSS, efisiensi penyisihan lebih baik pada akhir penelitian. Efisiensi penyisihan kandungan $\mathrm{BOD}_{5}, \mathrm{COD}$, dan warna yang baik pada awal penelitian dapat disebabkan oleh kemampuan tanaman Eceng Gondok pada awal penelitian yang masih baik dalam adsorpsi dan rhizofiltrasi karena belum banyak polutan yang diserap dan disaring pada akar tanaman.

Kemampuan adsorpsi Eceng Gondok yang menurun diakibatkan karena kandungan beban organik pada air limbah yang tinggi sehingga terjadi kejenuhan pada permukaan tanaman yang mengakibatkan beban organik pada air limbah tidak dapat diolah seperti pada awal pengolahan dengan Eceng Gondok. Jika dihubungkan dengan $\mathrm{pH}$, pengujian ke-4 memiliki efisiensi paling rendah pada setiap parameter yang diuji. $\mathrm{pH}$ pada pengujian ini adalah yang tertinggi yaitu 8,90 dibandingkan $\mathrm{pH}$ pada pengujian lainnya yang berada di bawah $\mathrm{pH}$ itu. Proses adsorpsi dipengaruhi oleh beberapa faktor antara lain sifat adsorbat, konsentrasi adsorbat, sifat adsorben, temperature, waktu kontak dan pengocokan, dan $\mathrm{pH}$ (Sawyer and Carty, 1987)
Hasil pengujian terhadap padatan tersuspensi sempat mengalami kenaikan konsentrasi dimana konsentrasi padatan tersuspensi yang pada awalnya adalah $12,1 \mathrm{mg} / \mathrm{ltd}$ an $8,8 \mathrm{mg} / \mathrm{lt}$ mengalami kenaikan menjadi 43,5 mg/lt dan 10,3 mg/lt. Hal ini dapat disebabkan oleh karena kotoran pada akar tanaman Eceng Gondok yang terlepas dan ikut mengalir terbawa oleh air. Selain itu adanya daun - daun tanaman yang layu dan sel sel yang mati kemudian terbawa oleh air limbah juga dapat menyebabkan padatan tersuspensi yang mengalami kenaikan konsentrasi. Menurut (Buddhari et al., 1984) senyawa beracun dan logam berat yang diserap oleh Eceng Gondok dari air yang tercemar akan diakumulasikan di akar dari pada pucuk daun. Akumulasi logam berat ini menyebabkan kerusakan struktur sel pada jaringan organ tumbuhan, dan kerusakan sel penutup stomata, sehingga akan mempengaruhi proses pertukaran gas dari luar ke dalam daun.

Pada percobaan reaktor batch, sampel air limbah yang digunakan adalah air limbah yang langsung dihasilkan oleh industri pencelupan tanpa melewati pre treatment sebelumnya. Pada percobaannya dilakukan beberapa kondisi yaitu dengan $\mathrm{pH}$ terkontrol dan tidak terkontrol, penambahan NPK (pupuk) dan tanpa penambahan NPK. Parameter yang diamati selama percobaan adalah kekeruhan, $\mathrm{pH}$ dan warna pada panjang gelombang 480

Pada variasi percobaan yang tidak dilakukan kontrol $\mathrm{pH}, \mathrm{pH}$ air limbah mencapai 10,55 sedangkan pada variasi dengan $\mathrm{pH}$ terkontrol nilai $\mathrm{pH}$ berkisar antara 7,97-8,02 (Tabel 2).

Tabel 2. Nilai pH Rata-rata setiap Variasi Percobaan

\begin{tabular}{lc}
\hline Variasi & pH Rata-rata \\
\hline Blanko & 7,49 \\
Blanko + NPK & 7,55 \\
Limbah + EG + pH kontrol & 8,02
\end{tabular}

Limbah + EG + pHkontrol + NPK 7,97 


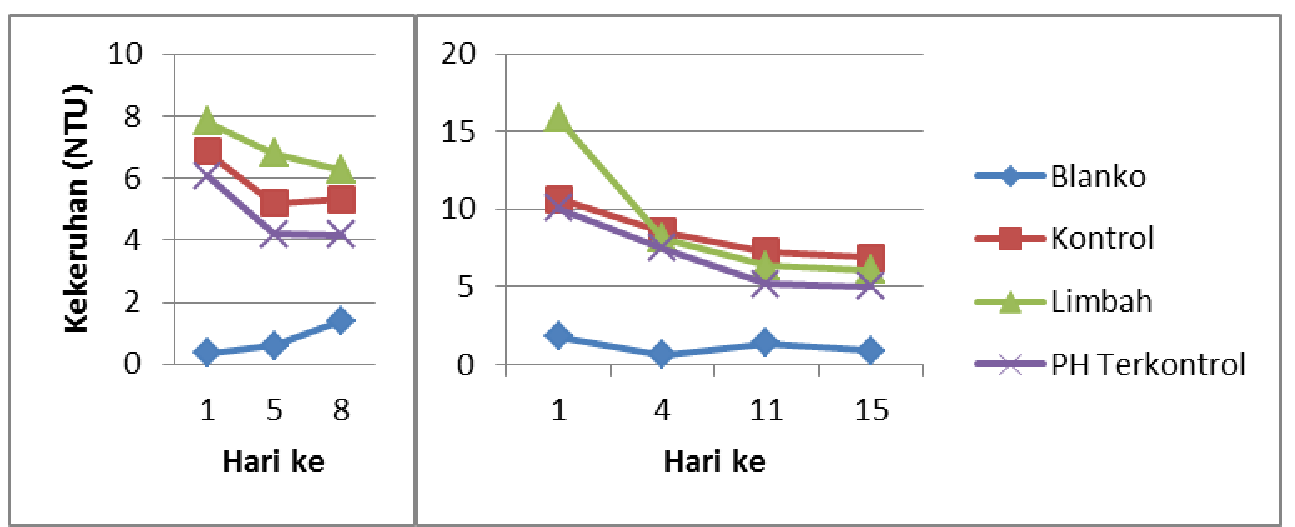

Gambar 3. Hasil Pengamatan Kekeruhan Percobaan 1 (kiri) dan 2 (kanan) tanpa penambahan pupuk NPK

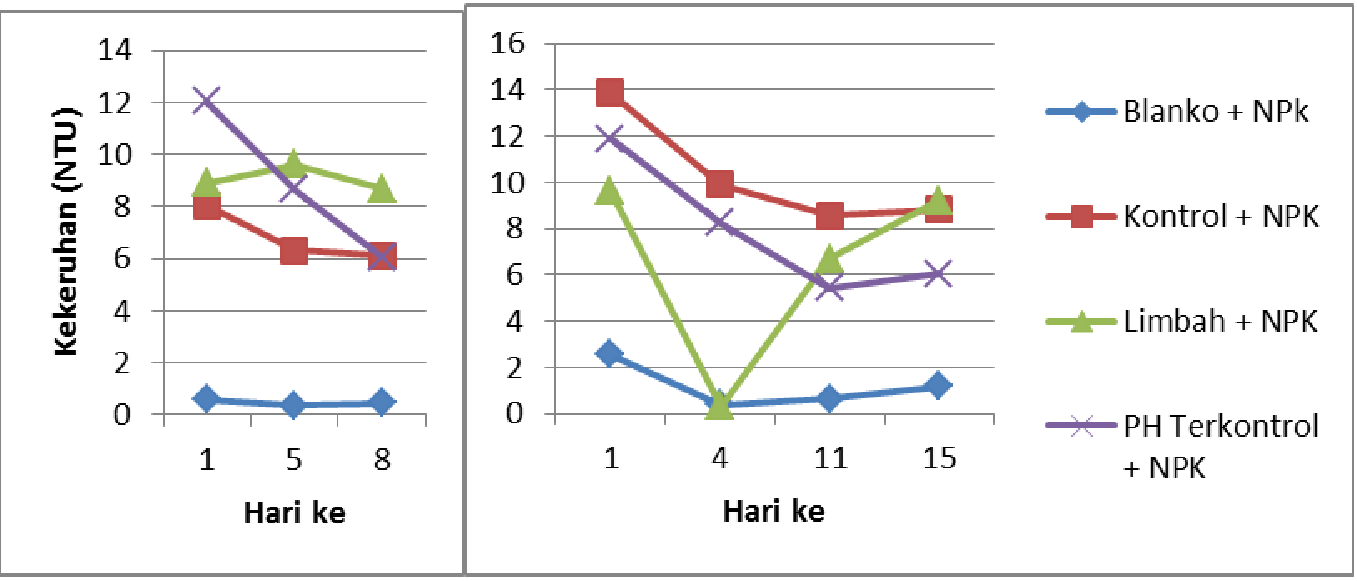

Gambar 4. Hasil Pengamatan Kekeruhan Percobaan 1 (kiri) dan 2 (kanan) dengan penambahan pupuk NPK

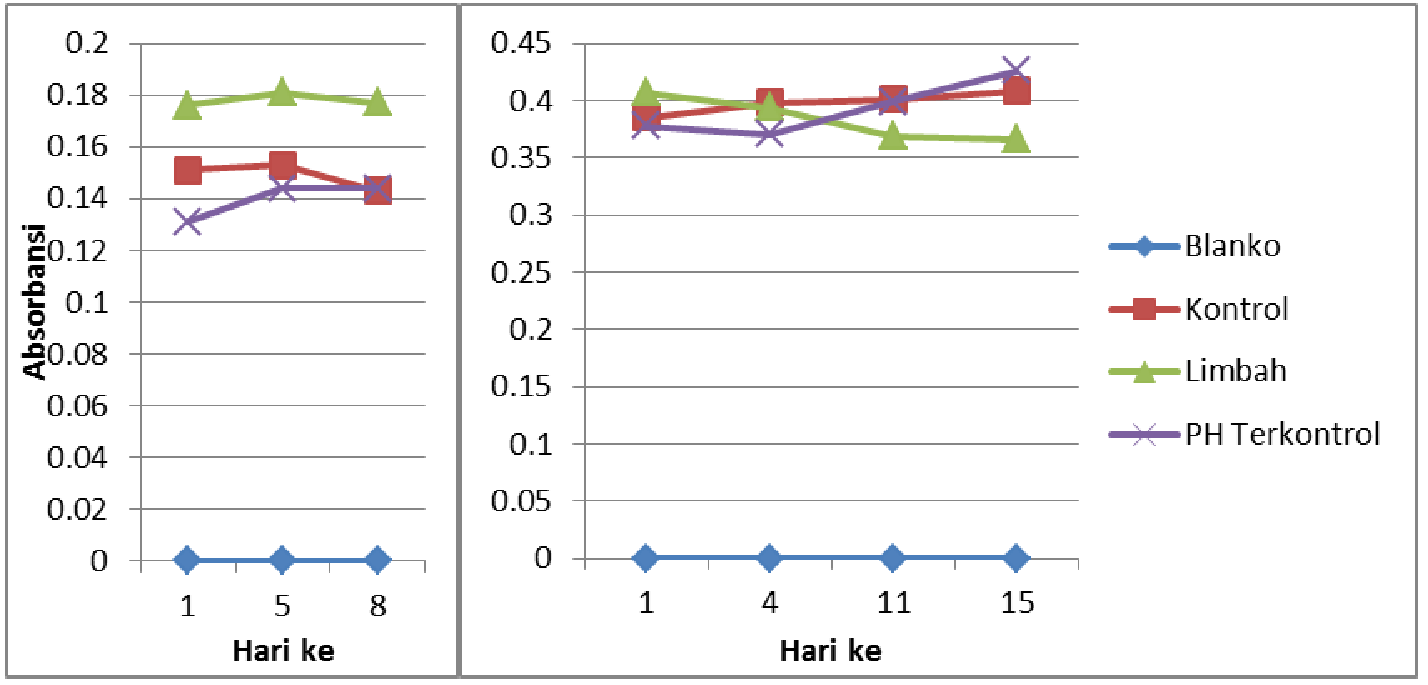

Gambar 5. Hasil Pengamatan Warna Percobaan 1 (kiri) dan 2 (kanan) tanpa penambahan pupuk NPK

Dari hasil percobaan reaktor batch terlihat bahwa enceng gondok sebenarnya tidak mampu menyisihkan zat warna air limbah textil yang belum melewati pre-treatment. Terlihat pada grafik 4.2 - 4.5, baik dengan maupun tanpa penambahan pupuk NPK yang bertujuan untuk meningkatkan pertumbuhan enceng gondok juga tidak memberi dampak pada kemampuan enceng gondok menurunkan konsentrasi warna dan kekeruhan. Penyesuaian nilai $\mathrm{pH}$ pada nilai netral sehingga sesuai dengan kondisi pertumbuhan enceng gondong juga tidak memberi pengaruh banyak pada kemampuan penyisihan warna dan kekeruhan. 


\section{DIRECTORY OF

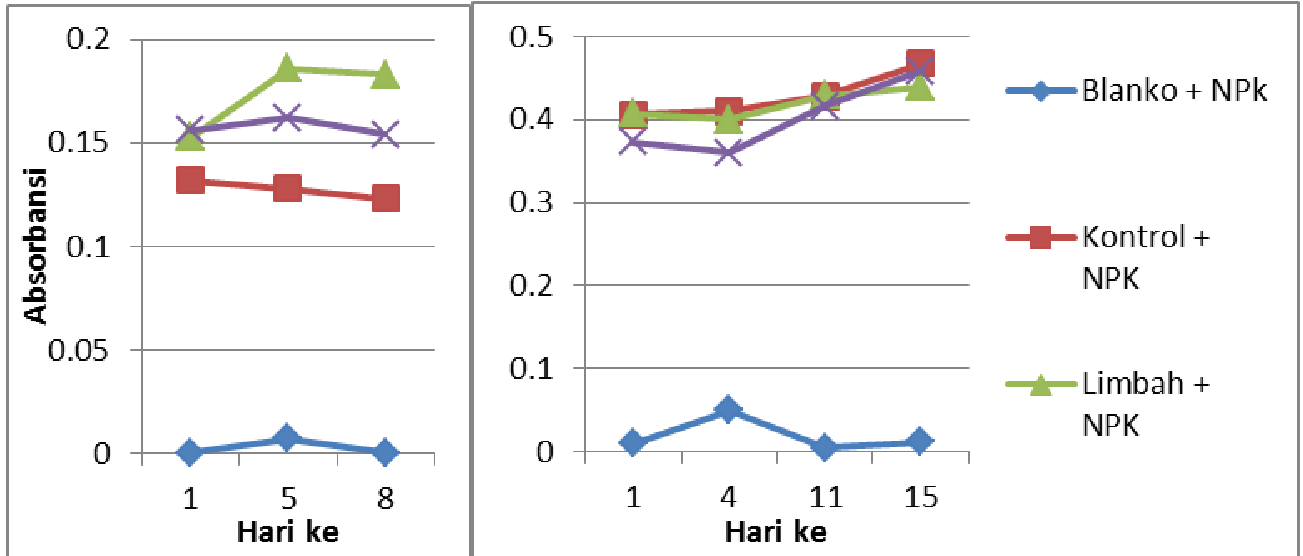

Gambar 6. Hasil Pengamatan Warna Percobaan 1 (kiri) dan 2 (kanan) dengan penambahan pupuk NPK

Berdasarkan penghitungan organic loading rate reaktor constructed wetland, diperoleh organic loading rate berkisar 424,57 kg/ha.hari sampai 2233,88 kg/ha.hari. Menurut (Metcalf and Eddy, 1993), BOD55 loading rate pada constructed wetland dengan tanaman Eceng Gondok dapat berkisar 10 sampai $300 \mathrm{~kg} / \mathrm{ha}$.hari. Tingginya organic loading rate ini menyebabkan efisiensi dari reaktor constructed wetland tidak berjalan maksimal. Tetapi walaupun Organic Loading Rate yang jauh melebihi kemampuan reaktor, tetapi reaktor ini mampu bekerja dalam menyisihkan kandungan BOD5, COD, TSS, dan warna yang ada pada air limbah. Berdasarkan hasil penelitian efisiensi penyisihan tertinggi diperoleh pada parameter BOD5, COD, TSS, dan warna adalah 53,09\%, $55,22 \%, 59,47 \%, 34,8 \%$.

Berdasarkan peraturan Kep.Men.51/Men.LH/10/1995 tentang baku mutu limbah cair industri tekstil maka dapat dilihat bahwa kualitas effluent air limbah tekstil dengan

\section{KESIMPULAN}

Efisiensi BOD5, COD, TSS, dan warna tertinggi diperoleh sebesar $53,09 \%, 55,22 \%, 59,47 \%, 34,8 \%$ dan terendah sebesar $11,06 \%, 8,31 \%, 6,84 \%, 7,54 \%$ dengan rata rata efisiensi yang didaptkan untuk parameter BOD5, COD, TSS, dan warna adalah $24,57 \%, 33,29 \%, 32,42 \%$, dan $19,06 \%$. Tanaman Eceng Gondok kurang efektif digunakan dalam pengolahan limbah tekstil karena pertumbuhan tanaman yang kurang baik dan rata - rata efisiensi pada setiap parameter masih berada dibawah $50 \%$ sehingga dapat dikatakan bahwa metode ini memiliki efisiensi yang rendah. Hal ini ditunjang dengan hasil percobaan dengan batch reaktor tanpa pengolahan pendahuluan, dimana tingkat absorpsi warna tanaman Eceng Gondok juga sangat rendah. Umur tanaman, konsentrasi warna, dan $\mathrm{pH}$ memiliki hubungan dengan menurunnya kemampuan Eceng Gondok dalam mengadsorpsi dan filtrasi kandungan BOD5, COD, TSS, dan warna yang ada pada air limbah tekstil.

Limbah tekstil yang menggunakan zat warna reaktif azo memerlukan pengolahan yang lebih kompleks karena bahan yang terkandung pada pewarna tekstil bersifat biodegradable. Pengolahan pendahuluan untuk mengolah limbah tekstil dapat dilakukan dengan proses kimia seperti dengan metode koagulasi.

Untuk penelitian selanjutnya dapat dilakukan dengan melakukan pengulangan proses minimal sebanyak 2 kali untuk mendapatkan hasil yang dapat membuktikan kinerja reaktor. Pada penggunaan tanaman Eceng Gondok dalam pengolahan limbah diperlukan tanaman yang berumur lebih muda karena tanaman yang umurnya lebih muda memiliki kinerja lebih baik. Penggunaan tanaman Eceng Gondok pada metode constructed parameter BOD5 dan COD bervariasi. Dari 7 sampel yang diperiksa dengan parameter BOD5, 3 hasil effluent belum memenuhi standar baku mutu air limbah karena masih di bawah standar yang ditentukan yaitu $60 \mathrm{mg} / \mathrm{lt}$. Ketiga hasil tersebut berturut - turut sebesar 93,6 mg/lt, $112 \mathrm{mg} / \mathrm{lt}$, dan $138,46 \mathrm{mg} / \mathrm{lt}$. Kemudian dari 7 sampel yang diperiksa dengan parameter COD, hanya 1 sampel yang belum memenuhi standar dimana standar untuk kandungan COD dalam air limbah tekstil adalah $150 \mathrm{mg} / \mathrm{lt}$ sedangkan salah satu hasil effluent air limbah setelah mengalami proses diperoleh hasil $307,68 \mathrm{mg} / \mathrm{lt}$. Kualitas effluent air limbah tekstil dengan parameter TSS secara keseluruhan sudah memenuhi standar baku mutu yang telah ditentukan yaitu minimal baku mutu untuk TSS adalah $50 \mathrm{mg} / \mathrm{lt}$.

wetland sebagai perlu regenerasi secara kontinyu karena dapat terjadi kejenuhan pada tanaman yang mengakibatkan menurunya kinerja tanaman dalam mengadsorpsi dan filtrasi.

\section{UCAPAN TERIMA KASIH}

Penulis mengucapkan terimakasih kepada CV. Tata Warna atas kesempatan dan dukungan sarana dan prasarana dalam melakukan penelitian ini.

\section{DAFTAR PUSTAKA}

Thygarajan, G. 1984. Proceedings of the International Conference on Water Hyacinth. Hyderabad, India, February 7$11,1983$.

Metcalf \& Eddy, Inc. 2004. Wastewater Engineering: Treatment and Reuse. 4th edition. McGraw-Hill Book Company. New York.

Sastrawidana, ID.K., Lay., W., Bibiana., Fauzi, M., Anas., S., Santosa., D. 2012. Pengolahan Limbah Tekstil Sistem Kombinasi Anaerobik-Aerobik Menggunakan Biofilm Bakteri Konsorsium Dari Lumpur Limbah Tekstil. Ecotrophic,3, 55-60.

Sawyer \& Carty, M. 1987. Chemistry for Engineering. Mc Graw-Hill Book Company. New York. 


\section{$\cap \leadsto \quad \begin{aligned} & \text { DIRECTORY OF } \\ & \text { OPEN ACCESS }\end{aligned}$}

Suyasa \& DWijani. 2007. Kemampuan sistem Passir-Tanaman Menurunkan Nilai $\mathrm{BOD}_{5}$ dan $\mathrm{COD}$ Air Tercemar Limbah Pencelupan. Ecotrophic, 2, 1-7. 